\title{
A CRÍTICA DO CRISTIANISMO COMO HISTÓRIA \\ EM KiERKEGAARD E EM BURCKHARDT: \\ DISTÂNCIAS E APROXIMAÇÕES
}

\author{
Marcio Gimenes de Paula \\ Universidade de Brasília, Brasil
}

\begin{abstract}
Se todos os anjos unissem seus esforços, eles ainda assim só seriam capazes de produzir uma aproximação, porque no que se refere ao conhecimento histórico uma aproximação é a única certeza ${ }^{1}$.
\end{abstract}

\begin{abstract}
Resumen
El objetivo de este trabajo es investigar la crítica del cristianismo como la historia en dos autores importantes: Kierkegaard y Burckhardt. Ambos, en profunda armonía con la investigación del siglo XIX, demuestran su interés por un tema importante de la época, a saber, la investigación de la importancia de la historia para entender los temas centrales del cristianismo. En Kierkegaard, especialmente en el Postscriptum, podemos ver el rechazo del cristianismo como fenómeno meramente histórico y la afirmación de los temas centrales de la posición cristiana como la subjetividad, el devenir y la decisión. En Burckhardt, sobre todo en sus Reflexiones sobre la bistoria y en sus Cartas, vemos el intento de comprender el cristianismo dentro del ámbito de la cultura y, al mismo tiempo, el reconocimiento de su independencia y autonomía. Por lo tanto, estos autores, a pesar de sus diferentes intenciones, parecen acercarse en sus investigaciones, lo que nos anima a valorar sus contribuciones, tanto en lo referente a la crítica del cristianismo, como lo que refiere a una crítica de la historia de la filosofía.
\end{abstract}

Palabras claves: Filosofía de la Historia, Filosofía de la Religion, Kierkegaard, Burckhardt, el siglo XIX.

\section{Abstract}

The purpose of this article is to investigate the criticism of Christianity as history in two important authors: Kierkegaard and Burckhardt.

${ }^{1}$ Søren Kierkegaard, Pós-Escrito às Migalhas Filosóficas - vol. I, Petrópolis: Editora Vozes, 2013, p. 35. 
Both in deep harmony with the research of the nineteenth century, show your interest for a very important issue of the period, namely the investigation of the importance of history to understand the central themes of Christianity. In Kierkegaard, especially in the Postscript to the Philosophical Fragments, we can see the rejection of Christianity as merely historical phenomenon and the affirmation of the central themes of the Christian position as subjectivity, becoming and the decision. In Burckhardt, especially in its Reflections on History and Letters, we see an attempt to understand Christianity within the scope of culture and at the same time, the recognition of their independence and autonomy. Thus, these authors, despite their different intentions, seem to approach in his research, which encourages us to assess their contributions both with regard to the criticism of Christianity as what matters to a critique of the Philosophy of History.

Key words: Philosophy of History, Philosophy of Religion, Kierkegaard, Burckhardt, Nineteenth Century.

\section{Resumo}

O objetivo desse artigo é investigar a crítica do cristianismo como história em dois importantes autores: Kierkegaard e Burckhardt. Ambos, em profunda consonância com as pesquisas do século XIX, mostram seu interesse por um tema bastante importante do período, a saber, o inquérito acerca da importância da história para a compreensão dos temas centrais do cristianismo. Em Kierkegaard, notadamente no Pós-Escrito às Migalhas Filosóficas, podemos perceber a recusa do cristianismo como fenômeno meramente histórico e a afirmação de temas centrais da posição cristã como a subjetividade, o devir e a decisão. Em Burckhardt, notadamente nas suas Reflexões sobre a História e nas suas Cartas, percebemos uma tentativa de compreender o cristianismo dentro do escopo da cultura e, ao mesmo tempo, o reconhecimento da sua independência e autonomia. Assim, tais autores, a despeito de suas intenções diversas, parecem se aproximar nas suas pesquisas, o que nos estimula a avaliar suas contribuições tanto no que tange à crítica do cristianismo como naquilo que interessa para uma crítica da Filosofia da História.

Palavras-chave: Filosofia da História, Filosofia da Religião, Kierkegaard, Burckhardt, Século XIX. 


\section{Considerações introdutórias}

Talvez um dos conceitos mais citados em qualquer léxico kierkegaardiano seja a palavra paradoxo. A sua explicação de forma mais cabal demandaria uma explicação mais detalhada e extensa. Entretanto, um aspecto nos chama a atenção: o tema do paradoxo está, na obra de Kierkegaard, estritamente vinculado com a crítica que o autor dinamarquês apresenta acerca das relações entre o cristianismo e a história. Especialmente no PósEscrito, onde toda a primeira parte tratará diretamente acerca do problema da verdade objetiva do cristianismo.

O fenômeno do cristianismo é histórico na medida em que ocorre, como diversas coisas do mundo, numa data precisa, isto é, surge dentro do tempo. Contudo, ao mesmo tempo em que ele é histórico, também possui outra faceta: ele depende da decisão do indivíduo. Assim, também se afirma como uma possibilidade para um indivíduo que, num instante determinado, o afirma e o segue ou, então, recusa a sua proposta. Portanto, entra aqui o caráter da decisão do indivíduo, aspecto de forte coloração subjetiva e existencial. Tal coisa nunca significou, para Kierkegaard, que o cristianismo não possa ter história e menos ainda que possa ter algum tipo de conteúdo objetivo. Contudo, visto que seu âmbito é o da eternidade, ele não ocorre meramente dentro do tempo mas, ao ocorrer dentro dele, afirma-se num tempo propício para que o indivíduo possa tomar a sua decisão de segui-lo ou recusá-lo. Logo, esse parece ser o contexto onde podemos compreender melhor a crítica kierkegaardiana ao cristianismo objetivo que se afirma no Pós-Escrito. Desse modo, tal como sugere Hannay, podemos nos aproximar daquilo que seria o seu objetivo geral nessa obra, tão bem expresso sob a pena do pseudonímico Climacus:

O ponto geral consiste no incorreto que resulta pensar no cristianismo como algo 'dado', algo frente ao qual alguém confia que poderá relacionar-se uma vez que deixe claro os atos de que é exatamente isso com o que alguém vai se relacionar. Climacus submete à consideração três desses enfoques, um dos quais se concentra na Bíblia, outra na Igreja e o terceiro que denomina 'prova do tempo'.2.

Kierkegaard é bem ciente das críticas recebidas pelo cristianismo depois do Iluminismo. Notadamente aquela que, desde os primeiros apontamentos,

${ }^{2}$ Alastair Hannay, Kierkegaard - uma biografia, Universidad Iberoamericana, Mexico, 2010, p. 347 
ainda no Tratado Teológico-Político de Espinosa, pareciam apontar para o problema em tomarmos como uma fonte confiável uma concepção que depende, no decorrer dos séculos, de inúmeros testemunhos. Assim, sua proposta articulada de crítica ao cristianismo como história não almeja, como foi um ideal de muitos pensadores do século XIX, harmonizar os conteúdos da fé cristã com a filosofia mas, antes, mostrar a particularidade do cristianismo e a exata distinção entre os assuntos de fé os assuntos de razão, ainda que isso não possa ser, em momento algum, tomado como irracionalismo. Aqui trata-se apenas de distinguir entre as coisas do transcendente e do imanente. O problema talvez residiria, portanto, numa discussão muito mais ampla sobre como o cristianismo, ao longo dos seus séculos de existência, compreendeu a relação entre as Escrituras e as provas de fé. Em outras palavras, aquilo que Evans aponta: “As Escrituras não podem, portanto, fornecer uma prova racional objectiva para o cristianismo que faria a fé desnecessária, uma vez que elas próprias são aceitas pela fé” ${ }^{3}$.

$\mathrm{Na}$ outra ponta de uma crítica do cristianismo como história nos séculos XIX e XX temos a instigante compreensão do fenômeno cristão apresentado por Jacob Burckhardt. Em sua imensa obra, o historiador suiço aponta, com argúcia, um aspecto que merece destaque: "Finalmente, até o protestantismo oficial, originado de um processo espiritual na sua essência, não pode mais opor resistência eficaz à avalanche de concessões que se viu forçado a fazer, a fim de poder sobreviver" ${ }^{4}$. Em outras palavras, o cristianismo, que teve uma energia vital nos seus primórdios ao substituir o antigo Império Romano, parece agora se converter totalmente em cultura e em política. A inconformidade com tal situação, sempre existente no seio do próprio cristianismo é, por sua vez, geradora do movimento que origina a Reforma Protestante tal como a conheceremos no século XVI. Contudo, como bem parece perceber Burckhardt, tal protestantismo para se afirmar institucionalmente precisa construir acordos e, desse modo, ao fazer concessões, talvez tenha comprometido a sua própria sobrevivência enquanto movimento. Ao olharmos tal com aspecto com mais cuidado, notamos que a crítica do pensador suiço e do pensador de Copenhague se encontram, ainda que as propostas e os objetivos sejam distintos. Para ambos, o pano de fundo do debate reside, na verdade, numa relação

\footnotetext{
${ }^{3}$ Stephen Evans, Kierkegaard's fragments and Postscript - The Religious Philosophy of Johannes Climacus, Atlantic Highlands: Humanities Press 1983, p. 255.

${ }^{4}$ Jacob Burckhardt, Reflexões sobre a história, Rio de Janeiro: Editora Zahar, 1961, p. 158.
} 
entre a cultura e a religião. Aliás, um dos temas centrais do século XIX, notadamente em contexto germânico e protestante, tal como avaliaremos na primeira parte acerca de Kierkegaard e na segunda parte, com enfoque nas reflexões de Burckhardt.

II. A investigação do cristianismo como bistória no Pós-Escrito às Migalhas Filosóficas de Kierkegaard

O Pós-Escrito às Migalhas Filosóficas de Kierkegaard data de 1846. Como o próprio nome indica, ele completa e aprofunda o tema daquela obra que o antecedeu e foi publicada, por sua vez, dois anos antes. Assim, uma das questões centrais apresentadas na primeira parte do Pós-Escrito, não despropositadamente, intitula-se o problema objetivo da verdade do cristianismo. Em outras palavras, trata-se de um tema central da época, a saber, a discussão da verdade histórica do cristianismo. Tal tese é, a rigor, retomada com forte ênfase pela filosofia hegeliana que, já a partir dos seus escritos juvenis do seu fundador, preocupou-se sobejamente com temas clássicos do cristianismo e da sua herança, fornecendo-lhe uma roupagem histórica. No século XIX, igualmente importante serão os escritos de Strauus e Bruno Bauer, que apontam na mesma direção e todo um debate, construído a partir disso, numa interpretação do conceito de história a partir de Hegel, como bem aponta Löwith:

O fundamento último para a construção histórico-final de Hegel reside na sua valorização absoluta do cristianismo, para cuja fé escatológica o fim e a plenitude dos tempos apareceu com Cristo. Por Hegel situar a esperança do fim dos tempos no curso dos acontecimentos do mundo, e o absoluto da fé cristã na razão da história, ele está sendo apenas consequente ao compreender a realização do começo como o último grande acontecimento na história do mundo e do espírito 5

Assim, dentro de tal contexto, mas na discordância com tal tese hegeliana, podemos inserir a crítica kierkegaardiana acerca do conceito de história no cristianismo.

As questões levantadas no Pós-Escrito - e que também já apareciam nas Migalhas- são as seguintes questões: pode haver um ponto de partida histórico para uma consciência eterna? Tal ponto pode interessar mais do que o ponto de vista histórico? Pode-se basear a felicidade eterna em um

\footnotetext{
${ }^{5}$ Karl Löwith, De Hegel a Nietzsche, São Paulo: Unesp, 2014, p. 42.
} 
conhecimento histórico? Em outras palavras, como os indivíduos colocamse, eles próprios, diante da história do cristianismo? No seu entender, a questão da história no cristianismo deve sempre levar em conta os indivíduos. Diferentemente do que ocorreu nas Migalhas, no Pós-Escrito o autor pseudonímico Clímacus se confessa como alguém simpático ao cristianismo e já na introdução da obra encontramos uma pergunta de cunho pessoal, isto é, "como posso eu, Johannes Climacus, tomar parte na bem-aventurança que o cristianismo promete?" ${ }^{.}$. Com efeito, não se trata apenas de entender objetivamente a história do cristianismo.

A primeira parte, que aqui nos interessa especialmente, trata do problema objetivo da verdade do cristianismo. Objetivamente falando, o cristianismo é algo posto, isto é, sua verdade é dada dentro do tempo. Todavia, existe algo mais no cristianismo do que uma faceta meramente objetiva. Para a fé é impossível a concepção de algo dado exteriormente, isto é, vindo de fora. Objetivamente o cristianismo é uma verdade histórica e filosófica. A verdade histórica é fruto do confronto de diversas informações e de um acúmulo de testemunhos dentro do tempo. Já a verdade filosófica leva à verdade eterna da doutrina dada historicamente, reconhecendo-a como válida. Em outras palavras, a verdade filosófica parece, aos olhos de Kierkegaard, dar um passo adiante da verdade histórica ou se preferirmos, o autor dinamarquês, como bom oponente, mas, ao mesmo tempo, herdeiro de Hegel, compreende a consciência filosófica em sentido amplo, tal como sugere Löwith: "De acordo com essa consciência histórica da filosofia hegeliana se formaram não apenas os seus discípulos e sucessores, mas também seus adversários” Assim, o pensador objetivo não pode conhecer ou reconhecer uma verdade subjetiva, antes terá de conviver, por exemplo, com a dúvida. É certo que tal afirmativa não implica que o pensador subjetivo - ou aquele que tem fé - seja desprovido de dúvidas. Por isso, a conclusão kierkegaardiana é radical: ou o pensador objetivo (também chamado de especulante) se convence pela fé acerca da verdade do cristianismo e reporta-se a ela, ou, então, ao toma-la por irracional, a abandona. Logo, tal fé pode ser o seu interesse infinito. Aquele que se encontra somente na contemplação objetiva não se interessa mais infinitamente pela decisão de tal questão, essa seria a atitude típica daquele que contempla objetivamente. Por isso, segundo Kierkegaard, o problema não é objetivo. O cerne do problema reside na decisão. Com efeito, sua

${ }^{6}$ Søren Kierkegaard, Pós-Escrito às Migalhas Filosóficas - vol. I, Petrópolis: Editora Vozes, 2013, p. 23.

${ }^{7}$ Karl Löwith, De Hegel a Nietzsche, São Paulo: Unesp, 2014, p. 42. 
resolução passa pelo subjetivo. Em outras palavras, Kierkegaard não nega uma história do cristianismo, mas a subordina a uma escolha do indivíduo, a uma opção feita dentro do tempo e com caráter decisivo. Por isso, aos seus olhos, uma observação histórica ou objetiva do cristianismo pode, na verdade, amputar o seu âmago que reside, de fato, numa reapropriação.

Logo, se o cristianismo for apenas documento histórico devemos saber tudo sobre a doutrina cristã e, desse modo, o compreenderemos na sua totalidade. Entretanto, ao caminharmos em direção à história não conseguimos alcançar um dos seus temas centrais, a saber, busca da felicidade eterna. Afinal, a felicidade eterna não é do âmbito da verdade histórica. Nesse sentido, seguindo uma pista do cerne da própria tradição cristã e, diríamos, do agostianianismo, a concepção kierkegaardiana acredita que voltar-se para sua interioridade fornece ao indivíduo melhores respostas do que uma busca histórica. No protestantismo, tradição da qual Kierkegaard é um herdeiro, um dos pontos centrais dessa busca histórica da verdade do cristianismo reside na análise das Escrituras mais do que no catolicismo, que carrega consigo não apenas uma análise da Escritura mas, igualmente, o peso da tradição como critério interpretativo. Assim, para Kierkegaard, ao buscarmos, numa análise dos textos bíblicos, o máximo de certeza, procedemos como os eruditos, mas não como alguém que opta existencialmente pela verdade do cristianismo. A teologia erudita, na visão do pensador de Copenhague, aprecia tal discussão. Porém, o que são tais coisas senão garantias dogmáticas? A crítica bíblica, que bebe nas fontes da objetividade, acaba por atacar o cristianismo por causa da questão histórica. Desse modo, a objetividade pode levar um tipo de cristianismo que só poderia ser seguido pelos doutores. Curiosamente, há uma instigante passagem da obra Temor e Tremor, onde o pseudonímico autor Johannes de Silentio, sugere, com extrema ironia que, talvez, o problema de Abraão não resida numa situação limite de fé, mas antes em saber bem hebraico e as sutilezas do texto em seu idioma original: "Esse home não era um exegeta erudito e não sabia hebraico; soubesse ele hebraico, e talvez tivesse entendido facilmente a história e Abraão"'. A filologia sacra coloca-se na condição de ciência e a teologia faz-se cega diante disso, ou seja, é feita uma equivalência entre saber e fé com a qual Kierkegaard não pode concordar. Tal coisa não ocorre por ele menosprezar o saber, mas apenas por não poder toma-lo como o critério para a fé. Menos ainda sua posição sobre a fé pode ser tomada como um tipo de fideísmo, visto que não menospreza o saber,

\footnotetext{
${ }^{8}$ Søren Kierkegaard, Temor e tremor, Lisboa: Relógio d’Água 2009, p. 57.
} 
mas apenas o separa em esferas, do mesmo modo que Leibniz, por exemplo, já teria feito na Teodicéia. Por isso, o pensador dinamarquês é severo crítico desse tipo de objetividade e da ideia de processo histórico mundial ao modo hegeliano e, nesse sentido, reage ao afirmar que o cristianismo jamais pode ser equivalente a história: "O cristianismo é espírito; o espírito é interioridade; interioridade é subjetividade; subjetividade é essencialmente paixão; e, em seu máximo, uma paixão infinita e pessoalmente interessada na felicidade eterna" ${ }^{\circ}$.

Além da investigação sobre as Escrituras, outro aspecto que deve ser abordado para a investigação da questão histórica no âmbito do cristianismo é a Igreja. O pensador dinamarquês anuncia que não vai atacar a dialética, tal como faz a Igreja Católica Romana, que assim procede para defender a presença invisível do Papa. Pelo contrário, pelo que notamos ele tenta reconstruir a dialética e afirmá-la e, por isso, ao colocar o objetivo como especulante, o distingue da dialética que, no seu entender, remonta as melhores tradições tanto do socratismo grego como do cristianismo. Segundo Kierkegaard, o protestantismo, após renunciar à Bíblia, procurou apoio e refúgio na estrutura eclesiástica, talvez repetindo os mesmos erros do catolicismo. Entretanto, existiria mesmo protestantismo aqueles que defendem a Bíblia plenamente. Kierkegaard os denomina de fanáticos da letra, seres sem paixão, espíritos cômicos e quixotescos. Nessa perspectiva, a Bíblia se configura para eles como uma espécie de objeto de aproximação para uma paixão infinita, o que é cômico. De igual maneira também é cômica a recusa da Bíblia para poder ir aos serviços religiosos da igreja, tal como faz, no entender do pensador dinamarquês, a maioria dos seus compatriotas. Tal como já aparece nas Migalhas Filosóficas, três autores serão de fundamental importância para a construção do projeto kierkegaardiano que visa entender o cristianismo como fenômeno histórico (apontando os seus limites): Leibniz, Lessing e Espinosa. Lessing levanta um questionamento importante sobre a verdade do cristianismo. Segundo Lessing, existem verdades de fato e verdades de razão, estando o cristianismo colocado nas verdades de fato. Aliás, tal distinção de verdades, já havia sido realizada por Leibniz tanto na Monadologia. Para o ponto de vista objetivo, a Bíblia acaba por decidir o que é ou não cristão, tornando-se a igreja uma espécie de refúgio da objetividade sempre que fazemos um acurado exame das Escrituras. Contudo, para

${ }^{9}$ Søren Kierkegaard, Pós-Escrito às Migalhas Filosóficas - vol. I, Petrópolis: Editora Vozes, Petrópolis, 2013, p. 38. 
Kierkegaard, se a verdade é espiritual, deve-se valorizar o interior e não a mediação, que é quem prova objetivamente.

A primeira dificuldade de um exame objetivo da Bíblia é que essa é tomada como uma peça. O Novo Testamento, por exemplo, torna-se historia e é levado ao ponto máximo da objetividade pelos teólogos. Tal crítica, aliás, o próprio Kierkegaard, já havia desenvolvido nas Migalhas Filosóficas, especialmente nos capítulos IV e V, intitulados a situação do discípulo contemporâneo e a geração posterior. Assim, se as coisas forem entendidas apenas objetivamente como pode o Novo Testamento falar do presente? Em outros termos, retornamos as mesmas dificuldades já apresentadas nas Migalhas Filosóficas. Para Kierkegaard, o passado não explica o presente e, menos ainda, o futuro. Historicamente, dentro desse modelo, a igreja acaba por se tornar sinônimo de cristianismo, o que nem sempre parece correto. Contudo, ser cristão é muito mais do que ser contemporâneo do seu mestre. É impossível, para a concepção kierkegaardiana, demonstrar pela históriaou pela dialética- em que se constitui efetivamente a Igreja. A explicação da sua natureza não residiria na esfera da história ou dos argumentos. Ainda mais: a Igreja não precisa explicar tudo historicamente ao se reportar à Bíblia. Afinal, ela afirma sua crença na iluminação pelo Espírito Santo. Iluminação que não é fornecida nem pela dialética e nem pelo ponto de vista objetivo. Se a história bastasse, o Espírito Santo seria inútil. Por isso, Kierkegaard entende o cristianismo como espírito, subjetividade e interioridade. O sacramento do batismo, por exemplo, é histórico ou uma decisão? Se o batismo for histórico, a dialética não passa de superstição, ou seja, mera ritualística.

O paradoxo do cristianismo é que, para aquele que crê, vale mais um dia do que um século. Vale o momento da decisão, ou seja, do instante que não é mera ocasião, como ocorria no socrático. Sua prova não é dada pela objetividade. A ideia da objetividade leva à consideração especulativa que, por sua vez, enxerga o cristianismo como fenômeno histórico. Em outras palavras, para tal concepção, a verdade do cristianismo está ligada ao pensar e só possível chegar até ela pela via especulativa. O cristianismo se torna, portanto, pensamento eterno. A ironia disso tudo é que a consideração especulativa é aquela que diz não ter nenhum pressuposto. Assim, a especulação afirma, a partir do nada, que nada lhe é dado e que não é mediada; no entanto, ela toma o próprio cristianismo como dado. Ao dizer que todos são cristãos, ela se torna por demais generosa, retirando a dificuldade do que significa ser cristão. Logo, o cristianismo parece ter se 
tornado, segundo o pensador de Copenhague, uma imposição estatal. A união do Estado com a religião, notadamente no contexto dinamarquês, conduz a uma pressão social inegável. Ser cristão parece apenas uma questão geográfica, isto é, se o indivíduo nasce num país dito cristão ele só pode, de igual modo, ser cristão. $\mathrm{O}$ mesmo ocorreria se ele tivesse nascido num país muçulmano. Para Kierkegaard, tal imposição é inaceitável, pois tira a decisão do indivíduo, transferindo a mesma ao Estado e à geografia.

\section{Burckhardt e a temática do cristianismo como história a partir das "Reflexões sobre a História e das Cartas"}

Karl Löwith é um autor que possui profunda consideração por Burckhardt a ponto, inclusive, de dedicar-lhe uma obra de fôlego, a saber, Jacob Burckbardt - o bomem o bomem no meio da história, escrita em 1936, período do seu exílio na Itália. O autor alemão o toma como um pensador profundo da sua época. A pergunta sobre a qual podemos, então, nos inquerir é: o que poderia haver enxergado Karl Löwith de tão importante na obra de Burckhardt? Segundo avaliamos, foi o senso histórico, tal como se pode atestar por essa pequena passagem de O Sentido da história: "O objetivo especifico da vida que Burckhardt dedicou ao estudo e ao ensino da história não foi nem construir filosoficamente uma história universal nem promover a investigação técnica, mas desenvolver o sentido da história” ${ }^{10}$. Em outras palavras, mesmo vivendo no século XIX, o pensador suíço não se deixa levar por uma perspectiva hegeliana, que compreende a história como história universal, e, menos ainda, deixa de ser crítico com a tese de uma investigação técnica o que, aliás, sempre lhe pareceu algo muito alheio a esfera das discussões em ciências humanas e ao conceito de formação tal como se pode compreendê-lo em contexto germânico (Bildung). Desse modo, a história não é uma ciência objetiva que investiga fatos neutros, mas sim como os fatos ocorridos em uma época repercutem em outra. Por isso, Löwith é contundente em seu elogio ao pensador suíço: "Ao invés de ser neutro e, por conseguinte, incapaz de julgar, Burckhardt foi o historiador mais crítico e conscientemente seletivo do século XIX. Mas nunca pretendeu ser filósofo" ${ }_{11}$.

Desse modo, a tarefa do historiador é muito mais modesta, tal como explicitará Burckhardt nas Reflexões sobre a História. A busca de sentido

${ }^{10}$ Karl Löwith, O Sentido da bistória, Lisboa: Edições 70, 1991, p. 33.

11 Ibid., p. 33. 
não ocorrerá nem tal como a havia pensado Santo Agostinho e nem como a havia pensado Hegel. O primeiro a pensou através da referência divina ou segundo tentou explica-la, ao modo sistemático, através do Espírito Absoluto. O pensador suíço avalia que o termo Filosofia da História comporta uma contradição e, por isso, almeja o sentido. Segundo suas palavras: Uma Filosofia da História constitui, na realidade, um elemento híbrido, uma contradictio in adjecto pois a História, ou seja: a coordenação de elementos, é a antitese da Filosofia e esta, isto é: a subordinação, o critério subordinador, é o oposto da História ${ }^{12}$. Para ele, um aspecto importante seria mantermos nossa objetividade perante os fatos, isto é, "que procuremos manter nossa objetividade perante os fenômenos históricos, abstendo-nos de introduzir neles elementos volitivos e que denotem pontos de vista subjetivos" ${ }^{13}$. Tal sentença parece, num primeiro momento, muito de acordo com alguns pressupostos hegelianos, mas tal percepção é falsa. No entender do pensador suíço, Hegel teria se equivocado nas suas premissas acerca do processo evolutivo do espírito, tal como se pode notar nas suas teses de A Filosofia da História. Curiosamente, Burckhardt acredita que tal tese, ocorreu mesmo com o pensador partindo "de premissas idôneas" ${ }^{14}$. O problema residiria, no seu entender, num tipo de planificação onde, a rigor, o espírito nunca cabe. Logo, afirma o pensador suiço:

Nosso ponto de partida é constituido pelo único elemento invariável e que consideramos passível de ser analisado: o ser humano, com seu sofrimento, suas ambições e suas realizações, tal como ele é, sempre foi e será, dai podermos afirmar que nossas considerações serão, até certo ponto, patológicas ${ }^{15}$.

Em outras palavras, trata-se de uma visão sobre a história que mesmo advogando a tese da objetividade não prescindirá do pathós, tal como também poderemos notar em Kierkegaard que, inspirado pelo tema da subjetivade em Sócrates e em Cristo, articulou uma espécie de aproximação - dentro dos limites possíveis - entre a herança grega e os temas típicos da herança cristã.

Curiosamente, a discussão do tema da fé - e do quanto o moderno debate sobre a Filosofia da História é agora uma trama de conceitos

${ }^{12}$ Jacob Burckhardt, Reflexões sobre a história, Rio de Janeiro: Editora Zahar, 1961, p. 10.

${ }^{13}$ Ibid., p. 9.

${ }^{14}$ Ibid., p. 10.

${ }^{15}$ Ibid., p. 12. 
teológicos secularizados - coloca Burckhardt, ele próprio, numa espécie de auto-reflexão. Por não possuir nenhuma experiência privada de fé, sentese incapaz de abordar o tema. Em outras palavras, se a fé é condição para compreender o processo de secularização, ele se acha inapto para a tarefa, o que, talvez, o aproxime nesse aspecto, por exemplo, de algumas das teses kierkegaardianas que parece tão bem explicitada aqui na afirmação de Löwith: "A solução religiosa do sentido da história pertence, segundo ele, a uma 'faculdade especial' do homem- à fé, que Burckhardt não fingia ter" ${ }^{16}$. O próprio Burckhardt, numa carta ao teólogo Willibald Beyschlag em 14 de janeiro de 1844, faz, inclusive, uma curiosa confissão pessoal que, segundo avaliamos, corrobora com a tese:

Sim, eu acredito que seu sentimento pela Igreja é genuíno consciencioso e verdadeiro. Sei que pessoas com respeito próprio mantêm-se fiéis à Igreja, e que o ponto de vista da Igreja ainda é inteiramente justificável e, sem dúvida, assim permanecerá por algum tempo. Pouco a pouco meus estudos convenceram-me de que também a Igreja Protestante, como guardiã do tesouro universal, é uma Igreja, e não apenas a débil imitação superficial da Igreja Medieval. E só posso respeitá-lo ainda mais por apegar-se a ela embora você não ignore o desdém e o desprezo que a Igreja tem de enfrentar, e apesar de saber que as principais mentes da nação a abandonaram. Eu rompi com a Igreja para sempre, por motivos demais pessoais, uma vez que, literalmente, não consigo encontrar sentido nela. Minha vida moral, sit venia verbo, segue em frente sem a ajuda da Igreja, e recua sem o aguilhão da consciência eclesiástica. A Igreja perdeu todo o poder sobre mim, assim como sobre muitos outros, o que, num período de dissolução, seria mais do que esperado ${ }^{17}$.

Por isso, o autor parece, no entender de Löwith, pender para um dado ceticismo. Visto que o ceticismo é aquilo que "tem como certeza o seu lugar num mundo em que se desconhece o princípio e o fim e em que o meio está em constante movimento" ${ }^{18}$. Contudo, sobrevivendo a esse tipo de ceticismo, o pensador suíço almeja encontra uma espécie de fio de continuidade entre os períodos históricos. Aqui parece residir o seu fio da meada na tentativa exposta nas Reflexões sobre a história. Em outras palavras, a busca de uma linha fina que se moveria entre teologia e filosofia e, tal continuidade "é mais do que o mero prosseguir, porque implica um esforço consciente de relembrar e renovar o nosso legado em vez de aceitar com impassividade

\footnotetext{
${ }^{16}$ Karl Löwith, O Sentido da bistória, Lisboa: Edições 70, 1991, p. 34.

${ }^{17}$ Jacob Burckhardt, Cartas, Rio de Janeiro: Topbooks, 2003, p. 186.

${ }^{18}$ Karl Löwith, O Sentido da bistória, Lisboa: Edições 70, 1991, p. 34.
} 
a amálgama de costumes" ${ }^{19}$. Assim podemos compreender sua crítica do progresso e igualmente entender sua defesa de uma espécie de missão, isto é, não apenas uma tentativa de superar sua época mas, ao contrário, a consciência de saber que deve preservá-la sob pena de perder a própria história e tradição. Avaliamos que a partir de tal juízo se pode compreender, por exemplo, sua radical crítica ao conceito de democracia igualitária, desenvolvido entre os séculos XVIII e XIX, como bem aponta Löwith:

Pensou que uma democracia radicalmente igualitária não conduziria à liberdade e a responsabilidade individuais, mas a uma mediocridade pretensiosa e a um tipo de despotismo. Temia que o socialismo econômico pudesse impulsionar um aparelho estatal superdesenvolvido, que qualquer demagogo mais ousado pudesse igualmente tomar e explorar, combinando a social democracia com a ditadura militar ${ }^{20}$.

Logo, ao contrário do surgimento no século XIX e XX de um Estado de paz social iluminista e inspirado em princípios liberais, Löwith ao interpretar Burckhardt, aponta que a humanidade irá assistir, atônita, ao pior dos rebaixamentos:

A vulgarização e a padronização da vida pareciam-lhe inevitáveis. Em vez de uma democracia liberal, previu o Estado totalitário governado por terrribles simplificateurs, que invadirão a Europa e a dominarão com atroz brutalidade, escarnecendo a lei e totalmente indiferentes à liberdade e à soberania do povo ${ }^{21}$.

O liberalismo e a defesa da tradição, dos quais Burckhardt possui nostalgia num século de mudanças, parecem ter dois aspectos centrais: segundo Löwith, o primeiro residiria num reconhecimento de que a história da humanidade não é uma história gloriosa mas, ao contrário, é sempre "um conhecimento concreto da nossa verdadeira situação: luta e sofrimento, efêmeras glórias e longas misérias, guerras alterando períodos de paz" ${ }^{22}$. Assim, seguindo uma tradição que prima pelos valores do indivíduo, Löwith avalia que, para Burckhardt, "a grandeza histórica de uma nação não compensa a aniquilação de um indivíduo que seja” ${ }^{23}$. Além da defesa de uma história dos homens concretos e dos indivíduos, o segundo ponto aqui a ser

\footnotetext{
${ }^{19}$ Ibid., p. 35.

${ }^{20}$ Ibid., p. 35.

${ }^{21}$ Ibid., p. 36.

${ }^{22}$ Ibid., p. 37.

${ }^{23}$ Ibid., p. 38.
} 
ressaltado é um elogio que o pensador suíço faz do religioso, exemplificado aqui, como precisão, na figura daqueles monges do deserto e dos primeiros mártires do cristianismo. Eles foram os preservadores da cultura europeia em meio ao mais crasso barbarismo, tal como aponta Löwith:

Para Burckhardt, estes homens não foram inúteis escapistas, mas 'heróis do deserto', que, após, uma luta tremenda, se tinham apercebido de uma profunda necessidade numa época de barbarismo civilizado. Sem o exemplo extremo destes primeiros monges e eremitas, a Igreja não teria mantido a integridade, tornando-se a única instituição espiritual que alimentou e preservou toda a educação de nível mais elevado. Contudo, Burckhardt afirma que nós, os que ainda tomamos como certas as investigações científicas, a liberdade do trabalho intelectual, costumamos esquecer a enorme dívida que temos para com a Igreja daquela Idade 'das Trevas' pelo cultivo de um conhecimento que não é mundano nem tem um objetivo prático ${ }^{24}$.

Acompanhando aqui um liberal como, por exemplo, Stuart Mill, que mesmo a despeito de não professar pessoalmente uma religião, a toma como importante para o corpo social25, Burckhardt, como mostra Löwith, "pensou que nenhuma educação liberal a não ser a religião, nos poderá salvar da grande violação da alma humana que atualmente se registra" ${ }^{26}$. Contudo, mais fortemente do que o pensador inglês, o professor da Basiléia escandaliza-se, ao modo kierkegaardiano, com o significado da cristandade no contexto europeu do século XIX. Por isso, ele, mesmo como filho de um pároco protestante, tal como seu colega Nietzsche, empreenderá o mesmo esforço do pensador dinamarquês para, tal como enfatiza Löwith buscar uma espécie de "cristianismo primitivo e autêntico, em perfeito contraste com as normas universais" ${ }^{27}$. Logo, a partir desse ponto, podemos compreender sua crítica à cristandade tal como a compreendemos em Kierkegaard e, num dado sentido, até mesmo os adversários do cristianismo como Feuerbach, que afirmava que "o cristianismo já está tão deturpado e em desuso que até mesmo os representantes oficiais e eruditos do cristianismo, não sabem mais ou pelo menos não querem saber o que é o cristianismo" ${ }^{28}$ e Nietzsche, que afirmava que "houve apenas um cristão e ele morreu na cruz" ${ }^{29}$. Tal

${ }^{24}$ Karl Löwith, O Sentido da história, Lisboa: Edições 70, 1991, p. 39.

${ }^{25}$ Tal tese é defendia por Mill na sua obra $A$ utilidade da Religião.

${ }^{26}$ Karl Löwith, O Sentido da história, Lisboa: Edições 70, 1991, p. 40.

${ }^{27}$ Ibid., p. 41.

${ }^{28}$ Ludwig Feuerbach, A Essência do cristianismo, Petrópolis: Editora Vozes, 2009, p. 19.

${ }^{29}$ Friedrich Nietzsche, O Anticristo, São Paulo: Companhia das Letras, 2007, p. 45. 
crítica é essencialmente voltada ao cristianismo moderno, isto é, aquele que consegue conjugar o cristianismo junto com os avanços da civilização secular, como bem indica Löwith:

Para o homem moderno, o Cristianismo não é um obstáculo nem uma loucura mas - se não lhe for hostil - um elemento salutar da civilização secular. A Cristandade moderna quer esquecer que o Cristianismo sempre se revelou bastante influente ao manter a divergência em relação à cultura universal. Em contraste com os cultos politeístas do paganismo clássico, a religião cristã não foi nem é um culto dedicado a uma cultura nacional, mas uma fé transcendente numa redenção futura ${ }^{30}$.

Ainda mais: esse tipo de crítica afirma-se essencial no século XIX, época onde o protestantismo de cunho liberal é muito forte em contexto germânico, por isso sua busca pela autenticidade ou pela honestidade o coloca, ainda que não com os mesmos objetivos, ao lado de Kierkegaard. Por isso, se Feuerbach foi um dia o aliado involuntário do pensador de Copenhague, o professor suíço talvez, alguns anos depois dele, talvez possa ser tomado também no mesmo registro, como bem avaliava Löwith: "Esta simples visão mais prática de Burckhardt é ainda mais extraordinária por ser a visão de um historiador secular do século XIX e não de um teólogo neo-ortodoxo do século XX" ${ }^{11}$.

Na mesma carta endereçada ao teólogo Willibald Beyschlag há uma passagem que merece menção:

Irei, de uma vez por todas, dizer claramente o que tantos viri doctissimi pensam e não ousam expressar: sob o nosso ponto de vista, o cristianismo entrou no domínio de períodos puramente humanos da história; o cristianismo guiou moralmente as nações; e lhes deu força e independência para que, de agora em diante, se reconciliassem, não com Deus, mas internamente, com suas consciências. O tempo dirá sob quais formas de pensamentos os povos germânicos e latinos poderão, mais uma vez, aproximar-se pessoalmente de Deus. Deus apenas tem de ser outra vez pessoal, e as pessoas acreditarão em Sua personalidade. Acredito que sua última encarnação vive em todos nós ${ }^{32}$.

Notemos a dupla força do argumento. De um lado o reconhecimento do valor do cristianismo para os povos germânicos e latinos, de outro a afirmação de que parece necessário buscar-se novamente algo perdido com

\footnotetext{
${ }^{30}$ Karl Löwith, O Sentido da bistória, Lisboa: Edições 70, 1991, p. 41.

${ }^{31}$ Karl Löwith, O Sentido da bistória, Lisboa: Edições 70, 1991, p. 42.

${ }^{32}$ Jacob Burckhardt, Cartas, Rio de Janeiro: Topbooks, 2003, pp. 187-188.
} 
a secularização: um Deus pessoal, tal como preconizava a antiga herança judaico-cristã. Por isso, nesse mesmo sentido, uma outra passagem da mesma carta, é igualmente profunda e instigante. Nela, o pensador afirma, mesmo com o seu ceticismo conceitual, o quanto gostaria de ter seguido a figura de Jesus de Nazaré:

Oh, tivesse eu vivido quando Jesus de Nazaré caminhava pelo interior da Judéia - eu O teria seguido, e teria deixado que o orgulho e a arrogância se dissolvessem no amor por Ele e não mais teria pensado em minha própria independência e valor - , pois quando se está perto de Dele, que importância teria perde-se como indivíduo? ${ }^{33}$.

Contudo, aqui é preciso cuidado: o que parece efetivamente interessar ao pensador suíço é a figura de Jesus enquanto homem, enquanto um marco da história da humanidade, uma admiração por um tipo psicológico, herança partilhada com seu colega Nietzsche ${ }^{34}$ :

Mas apesar de ansiar por Ele, dezoito séculos nos separam, e é somente quando estou sozinho e em momentos de melancólicos anseios que a majestosa imagem aparece diante de minha alma e me consola, a imagem do Maior dos Homens. Como Deus, Cristo me é indiferente - o que se pode pensar Dele dentro da Trindade? Como homem, Ele é a luz de minha alma, porque é a mais bela figura história. Quem quiser que chame isso de religião - não há nada que eu possa fazer contra esse conceito... No que me diz respeito, pense o que quiser; não tenho a pretensão de chamar isso de religião ${ }^{35}$.

Em outras palavras, uma religião sem religião, tema instigante do século XIX e XX. Talvez, a melhor descrição do tipo de posição de Burckhardt tenha sido formulada por Guardini que, na sua importante obra $O$ fim da Idade Moderna, afirma:

A angústia da Idade Moderna, ao contrário é devida em grande parte ao sentimento de não ter nem um lugar simbólico, nem um refúgio que seja imediatamente convincente; e também da experiência sempre renovada de não encontrar no mundo um lugar para a existência e que satisfaça a sua necessidade de sentido ${ }^{36}$.

${ }^{33}$ Ibid., p.188.

${ }^{34}$ Muito bem exposta nos aforismos 28 a 33 de O Anticristo.

${ }^{35}$ Jacob Burckhardt, Cartas, Rio de Janeiro: Topbooks, 2003, p. 188.

${ }^{36}$ Romano Guardini, O fim da Idade Moderna, Lisboa: Edições 70, 2000, pp. 37-38. 


\section{Considerações finais}

Numa carta de 7 de julho de 1878, destinada ao amigo Von Preen, Burckhardt relata um curioso episódio:

Recentemente um pastor da Igreja Reformada foi escolhido por meio das mãos daqueles que não vão à igreja, e para a infelicidade dos que vão. Como você sabe, eu não pertenço a esta última categoria; houve um tempo que eu estudei teologia por quatro semestres com o maior interesse, e então descobri que não possuía a fé exigida pelo púlpito, e, assim, me transferi para o campo da história. Mas o que não posso entender é a audácia de um reformista ocupar um púlpito e até realizar rituais em cujo significado ele não acredita! Como ele pode se impor a uma congregação após obter o cargo como resultado de um malentendu, a saber, como resultado do voto dado aos que, pressupõe-se, pertençam à congregação, quando, na verdade, trata-se de uma congregação que não existe? ${ }^{37}$.

Se observarmos o relato do episódio com vagar, facilmente podemos perceber o quanto a crítica do pensador suíço aqui explicitada aproximase, por exemplo, da crítica kierkegaardiana à cristandade. Para ambos, o cristianismo exigia seriedade Burckhardt, ciente daquilo que podia fazer e da sua descrença, o recusa não por menosprezo mas, ao contrário, por levar muito a sério sua proposta e por saber que não seria capaz de cumpri-la. Kierkegaard, com sua comunicação indireta e com seus pseudônimos, leva a crítica do cristianismo ao ápice da ironia não por zombar ou escarnecer dele, mas, ao contrário, para chamar a atenção sobre a seriedade que ele merecia numa era onde muitos do que parecem professá-la e ensiná-lo, em verdade, o desprezam e já o colocaram num mesmo plano das coisas desse mundo e, nesse sentido, profanaram o melhor do cristianismo e também o melhor da herança grega clássica. Assim, ambos os autores parecem, por perspectivas diversas, chamar atenção para o mal-entendido acerca do cristianismo.

Como bem acentua Alexander Dru, a maior parte dos amigos de Burckhardt, se situariam num curioso ambiente de disputa entre ortodoxos e liberais, mas ele próprio, talvez tenha sido apenas uma espécie de herege bonesto:

A maioria dos amigos de Burckhardt encontrava-se, a princípio, entre os 'ortodoxos', mas logo foram envolvidos pela primazia do racionalismo, embora posteriormente alguns deles voltassem a adotar pontos de vista

${ }^{37}$ Jacob Burckhardt, Cartas, Rio de Janeiro: Topbooks, 2003, p. 324. 
mais conservadores. Burckhardt não se alinhava com partido algum e, ao mesmo tempo em que admitia a força da crítica racionalista à posição 'ortodoxa', nunca aceitou a reinterpretação do cristianismo que se seguiu, e uma das consequências duradouras de suas discussões nessa época foi uma vitalícia aversão por teólogos liberais e desprezo por suas filosofias hegelianas da fé. Em oposição a elas que Burckhardt fala sobre permanecer um herege 'honesto'. A honestidade intelectual de suas posições que o deixou livre para o futuro, é remanescente da rejeição de Kierkegaard pelos 'ortodoxos' e racionalistas, objetos de tantos de seus primeiros comentários em seu Diário ${ }^{38}$.

Assim, ele próprio, tal como o pensador dinamarquês parece haver se posicionado na curiosa linha fronteiriça que o torna objeto de crítica dos racionalistas e dos ortodoxos, tal como acontecerá ao filósofo de Copenhague. Para ambos, a admissão de certas teses ortodoxas iria contrariar uma investigação de caráter mais abrangente mas, ao mesmo tempo, a admissão de algumas das premissas do liberalismo seria como fazer brotar o cristianismo do paganismo, o que os dois autores, mesmo que por razões diversas, rejeitariam. Talvez Kierkegaard e Burckhardt se aproximem num dado tipo de nostalgia: já não é mais possível nem sermos gregos ao modo clássico e, por outro lado, a cristandade sepultou o verdadeiro significado do cristianismo e, por isso, não fortuitamente o pensador de Copenhague parece fazer tantos esforços para a busca do tipicamente cristão ou da cristicidade. Por isso, Guardini pode ter razão quando pontua tal aspecto:

O não cristão de hoje julga muitas vezes que se pode desligar do cristianismo e procurar na Antiguidade outro caminho religioso. Mas engana-se. Não podemos regressar ao passado. Como forma de existência a antiguidade já não tem mais a dizer: está definitivamente ultrapassada. Se o homem de hoje se torna pagão é num sentido radicalmente diferente do do homem antigo. Em toda a grandeza da sua vida e da sua obra o homem da Antiguidade tinha uma atitude religiosa cheia de ingenuidade juvenil. Vivia antes da decisão que o Cristo vem realizar. Soeren Kierkegaard explicou definitivamente que uma decisão, qualquer que seja ela, projeta o homem num outro nível de existência ${ }^{39}$.

Aqui talvez, por diferentes registros, encontram-se o irônico de Copenhague e o berege honesto da Basiléia. Um encontro tão importante quanto fascinante. Certamente, merecedor de maiores investigações.

${ }^{38}$ Cfr., Jacob Burckhardt, Cartas, Rio de Janeiro: Topbooks, 2003, pp. 57-58.

39 Romano Guardini, O fim da Idade Moderna, Lisboa: Edições 70, 2000, p. 84. 


\section{Bibliográfia}

Burckhardt, Jacob, Cartas, Rio de Janeiro: Topbooks, 2003.

—, Reflexões sobre a história, Rio de Janeiro: Editora Zahar, 1961.

Evans, C. Stephen, Kierkegaard's fragments and Postscript - The Religious Philosophy of Johannes Climacus, Atlantic Highlands: Humanities Press, 1983.

Feuerbach, Ludwig, A Essência do cristianismo, Petrópolis: Editora Vozes, 2009.

Guardini, Romano, O fim da Idade Moderna, Lisboa: Edições 70, 2000.

Hannay, Alastair, Kierkegaard-umabiografia, México: Universidad Iberoamericana, 2010.

Kierkegaard, Søren, Migalhas Filosóficas, Petrópolis: Editora Vozes, 1995.

—_, Pós-Escrito às Migalhas Filosóficas - vol. I, Petrópolis: Editora Vozes, 2013.

—, Temor e tremor, Lisboa: Relógio d’Água, 2009.

Löwith, Karl, De Hegel a Nietzsche, São Paulo: Unesp, 2014.

—., O Sentido da história, Lisboa: Edições 70, 1991.

Nietzsche, Friedrich, O Anticristo, São Paulo: Companhia das Letras, 2007. 
